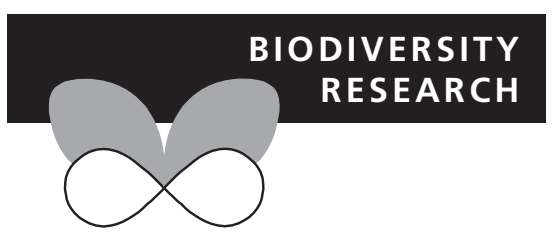

\title{
Contrasting effects of climate change along life stages of a dominant tree species: the importance of soil-climate interactions
}

\author{
Beatriz Ibáñez ${ }^{1 \star}$, Inés Ibáñez ${ }^{2}$, Lorena Gómez-Aparicio ${ }^{1}$, \\ Paloma Ruiz-Benito ${ }^{3,4}$, Luis V. García ${ }^{1}$ and Teodoro Marañón ${ }^{1}$
}

${ }^{1}$ Instituto de Recursos Naturales $y$ Agrobiología de Sevilla, Avda Reina Mercedes 10, 41012 Seville, Spain, ${ }^{2}$ School of Natural Resources and Environment, University of Michigan, 440 Church Street, Ann Arbor, MI 48109, USA, ${ }^{3}$ Forest Ecology and Restoration Group, Department of Life Sciences, University of Alcalá, 28871 Alcalá de Henares (Madrid), Spain, ${ }^{4}$ Biological and Environmental Sciences, School of Natural Sciences, University of Stirling, FK9 4LA Stirling, UK

*Correspondence: Beatriz Ibáñez, Instituto de Recursos Naturales y Agrobiología de Sevilla, Avda Reina Mercedes 10, 41012 Seville, Spain. E-mail: bibanez@irnase.csic.es

\begin{abstract}
Aim For tree species, adult survival and seedling and sapling recruitment dynamics are the main processes that determine forest structure and composition. Thus, studying how these two life stages may be affected by climate change in the context of other abiotic and biotic variables is critical to understand future population trends. The aim of this study was to assess the sustainability of cork oak (Quercus suber) forests at the core of its distributional range under future climatic conditions.
\end{abstract}

Location Southern Spain.

Methods Using forest inventory data collected at two periods 10 years apart, we performed a comprehensive analysis to evaluate the role of different abiotic and biotic factors on adult survival and recruitment patterns.

Results We found that both life stages were influenced by climatic conditions, but in different ways. Adult tree survival was negatively impacted by warmer spring temperatures, while recruitment was positively affected by warmer winter temperatures. Our results also revealed the importance of soil texture as a modulator of winter precipitation effects on adult survival. With higher winter precipitation, adult survival increased in sandy soils and decreased in clayish soils. Therefore, under predicted future climate scenarios of wetter winters and warmer temperatures, the presence of cork oaks is more likely to occur in sandy soils vs. clayish soils. Biotic conditions also affected these life stages. We found a negative effect of heterospecific but not conspecific trees on both adult survival and seedling recruitment.

Main conclusions Overall, the sustainability of the studied forests will be highly dependent not only on future climatic trends, but also on their interaction with other key factors - soil properties in particular - that modulate the effects of climate on demographic rates.

\section{Keywords}

Bayesian analysis, declining forest, demographic rates, establishment, forest inventory data, Mediterranean region.

\section{INTRODUCTION}

In forest ecosystems, mature tree survival and regeneration dynamics have long been recognized as the underlying processes determining forest structure and composition (Franklin et al., 1987; Kobe, 1996; Lewis et al., 2004) and hence, as the drivers of forest properties (Canham \& Pacala, 1994;
Pacala et al., 1996). Thus, changes in demographic rates at any of these stages could have great impact on the overall dynamics of forest ecosystems (Kobe, 1996). In the last decades, many forests have experienced a decrease in adult tree survival and/or recruitment because of global change-related events (Peñuelas et al., 2007; Lloret et al., 2009; Allen et al., 2010). In particular, increasing temperatures and drought 
events linked to climate change have been proposed as the likely drivers of recent tree decline in temperate ecosystems (van Mantgem et al., 2009; Carnicer et al., 2011; Vilà-Cabrera et al., 2012). Tree seedling recruitment has also been shown to be negatively affected by drier conditions (Lloret et al., 2004; Ibáñez et al., 2007). As a species' response to environmental stressors may differ, in direction and magnitude, among its different life stages (Cavender-Bares \& Bazzaz, 2000; He et al., 2005; Niinemets, 2010), its persistence would depend on the net effect across all stages (Phillips \& Gentry, 1994). Still, there is a surprising lack of studies exploring how a given global change driver (e.g. increase in temperature or reduced water availability) could simultaneously affect different life stages in the plant cycle, hampering our ability to predict the effects of future climate on forest ecosystems.

In an era of global change, with heavily modified landscapes and unprecedented rates of climate change, understanding how demographic rates of dominant species in forest systems could be affected by the future trends will be critical to successfully conserve and manage these ecosystems. Many forests world-wide have been highly modified by humans, giving rise to semi-natural forest types (Noble \& Dirzo, 1997; Axelsson \& Ostlund, 2001), frequently characterized by a dominant woody species (Bengtsson et al., 2000) whose persistence will depend on human activities (Urbieta et al., 2008; Brudvig \& Damschen, 2011; Bugalho et al., 2011). In the south-west of the Iberian Peninsula (Portugal and Spain), humans have highly impacted forest composition for centuries, increasing the dominance of sclerophyllous Quercus species (mainly Q. suber, cork oak) forming either agro-forestry systems known as 'montado' in Portugal or 'dehesa' in Spain (Olea \& San Miguel-Ayanz, 2006) or closed forests in areas with higher precipitation (Urbieta et al., 2008). In both ecosystems, dehesa and close canopy forest, the dominant woody species are a major structural element in these forests, frequently considered a 'keystone species'. Oak trees maintain ecosystem functions and services, such as protection from soil erosion, enhancement of plant and animal diversity (Marañón et al., 1999; Reyes-López et al., 2003; García et al., 2011), provisioning resources (e.g. cork, livestock feed) and cultural services (e.g. hunting, recreation) (Olea \& San Miguel-Ayanz, 2006; Marañón et al., 2012). Although these forests have been managed and sustained for hundreds of years (Plieninger et al., 2003; Bugalho et al., 2011), their long-term viability could be threatened by the current decline in adult oak trees, arising from both abiotic (e.g. recurrent drought periods) and biotic (e.g. soil-borne pathogens) factors (Brasier, 1995; David et al., 2004). This phenomenon, together with the lack of regeneration mainly due to seed predation (Pausas et al., 2009; Pérez-Ramos \& Marañón, 2012), massive seedling mortality during the summer (Gómez-Aparicio et al., 2008) and seedling predation by domestic and wild herbivores (Pulido \& Díaz, 2005; Pausas et al., 2009), highlights the uncertainty of the sustainability of this ecosystem and the services it provides.
Cork oak is distributed along the Mediterranean Basin, this is a region expected to undergo substantial increases in temperature and aridity in the next decades (IPCC, 2007; Planton et al., 2012), and it is considered one of the most vulnerable areas in the world under the predicted scenarios of climate change (Brunet et al., 2007; Giorgi \& Lionello, 2008). To assess the future of cork oak forests at the core of the species' distributional range, we carried out a comprehensive study that focused on the two main processes determining the future of this species: mature tree survival and regeneration patterns. Specifically, we used forest inventory data collected across Southern Spain to answer the following questions: (1) Are adult tree survival and recruitment dynamics equivalent along sites with different temperature and precipitation regimes? (2) How do other abiotic and biotic variables, and their interactions with climate, affect cork oak dynamics? (3) How will predicted changes in temperature and/or precipitation potentially affect adult tree survival and/or regeneration? By answering these questions, we aim to evaluate the specific life stage responses to environmental factors of $Q$. suber and to provide an overview of the current and likely future trends of this important declining species.

\section{METHODS}

\section{Study area and tree species}

The study area, Andalusia, is located in the West Mediterranean region, at the southern portion of Spain $\left(7^{\circ} 31^{\prime}\right.$ $\mathrm{W}-1^{\circ} 39^{\prime} \mathrm{W}, 37^{\circ} 33^{\prime} \mathrm{N}-37^{\circ} 23^{\prime} \mathrm{N}$, Fig. S1 in Supporting Information). It covers $87,268 \mathrm{~km}^{2}$, and the climate is typical Mediterranean, with cool, humid winters and warm, dry summers. Forested areas in Andalusia cover near $40 \%$ of the total surface, Quercus being the predominant tree genus in these forests (Urbieta et al., 2011).

Quercus suber, the study species, is a dominant tree in these landscapes. This is an evergreen species of great economic and ecological importance, present across 240,000 ha in the region. Cork oaks have low tolerance to extremely cold temperatures (frost) and severe droughts (they are rare in areas below $600 \mathrm{~mm}$ of annual rainfall), and they tend to prefer sandy soils (Aronson et al., 2009). In Andalusia, Q. suber is distributed into two main subregions with varying precipitation: Alcornocales Natural Park (1031.8 \pm $172.5 \mathrm{~mm}$ of annual precipitation, hereafter referred to as wet region) and Sierra Morena $(767.3 \pm 96.6 \mathrm{~mm}$, hereafter dry region). In the wet region, forests have predominantly closed canopies (mean basal area \pm SD $15.27 \pm 8.84 \mathrm{~m}^{2}$ $\mathrm{ha}^{-1}$ ), while the dry region is mainly a savanna-like scrubland $\left(10.21 \pm 6.98 \mathrm{~m}^{2} \mathrm{ha}^{-1}\right.$; Table S1 for a summary of the main characteristics of the studied plots).

Cork oak can form mono-specific stands, but it is also frequently found intermingled with other species. Olea europaea var. sylvestris and Quercus canariensis, a winter deciduous oak, are the most common companion tree species in the 
wet region, while Quercus ilex is dominant in the dry region. Cork oak trees are extensively managed for cork production, except in highly protected reserves (García et al., 2011).

\section{Forest inventory data}

We used the Spanish National Forest Inventory (SNFI) dataset to investigate patterns in adult tree survival and natural regeneration of $Q$. suber in this region. We used the Second and Third SNFI censuses, where data were collected during the years 1995-1996 (SNFI2) and 2006-2008 (SNFI3). Stands were located on a grid of $1 \times 1 \mathrm{~km}$ in forested areas and of $2 \times 2 \mathrm{~km}$ in savanna-like scrublands (Villaescusa \& Díaz, 1998). The stands are circular and composed of four concentric subcircles with radii $25,15,10$ and $5 \mathrm{~m}$ each, defining four different areas where trees are sampled according to size [minimum diameter at breast height (dbh) threshold of 42.5, $22.5,12.5$ and $7.5 \mathrm{~cm}$, respectively]. Trees within the stand were identified, measured (dbh) and mapped within the stand. The datasets contain information on recruitment as well (seedlings and saplings smaller than $1.30 \mathrm{~m}$ or $\mathrm{dbh}<7.5 \mathrm{~cm}$ ), measured within the 5 -m-radii circle (Villaescusa \& Díaz, 1998; Villanueva, 2004).

Stands were included in the analysis of adult tree survival if at least one mature cork oak tree $(\mathrm{dbh}>7.5 \mathrm{~cm})$ was measured. We discarded those stands with evidence of forest management (cutting or thinning) in the SNFI3 (accurately detailed in the database), resulting in a total of 755 stands used in the analysis. We then analysed changes in the number of trees present in each stand at time 1 (SFNI2), $\mathrm{N}_{1}$, and at time 2 (SFNI3), $\mathrm{N}_{2}$. As individuals were identified by their position within the concentric circles, we were able to discard in-growth trees, that is, those individuals with diameters growing above the $7.5 \mathrm{~cm}$ threshold during the two censuses.

For the analysis of natural regeneration, based on the SFNI3 census, we discarded the stands with reforestation activities. We worked with a total of 737 stands. The number of seedlings and saplings was recorded in ordinal categories: small seedlings (height $<0.30 \mathrm{~m}$ ), large seedlings (height between 0.30 and $1.30 \mathrm{~m}$ ), small saplings (height $>1.30 \mathrm{~m}$ and $\mathrm{dbh}<2.5 \mathrm{~cm}$ ) and large saplings (height $>1.30 \mathrm{~m}$ and $2.5<\mathrm{dbh}<7.5 \mathrm{~cm})$.

\section{Abiotic and biotic predictors}

The selected stands were characterized by 20 abiotic and two biotic variables. The abiotic factors included ten climatic, eight edaphic and two topographic variables. The ten climatic variables, calculated from Gonzalo's (2008) map with a $1-\mathrm{km}^{2}$ spatial resolution, were annual precipitation $(\mathrm{mm})$ and seasonal precipitation (spring, summer, fall and winter), and mean annual and seasonal temperature $\left({ }^{\circ} \mathrm{C}\right)$ (Table S2). We carried out a preliminary analysis and ran different models (see below for an in-depth description of the type of models used) that we parameterized with each one of the climatic variables. We compared those models to evaluate the most influential temperature and precipitation measurements within the year, which were then selected for further analysis. The eight edaphic variables were estimated from different maps and models developed for the study area (De la Rosa et al., 2002; De la Rosa \& Monge, 2006; Monge et al., 2008; see Table S2), calculated for the first $50 \mathrm{~cm}$ of soil and included $\mathrm{pH}$, clay, sand and silt content (\%), organic matter (\%), soil water content at field capacity (g/ $100 \mathrm{~g})$, soil bulk density (g/cc) and available water capacity (g/100 g). To avoid convergence problems during parameter estimation, we applied a principal component analysis (PCA) followed by a varimax rotation to discard those soil variables which were highly correlated ( $\mathrm{R}$ Development Core Team, 2009). This approach was chosen to minimize the shared variance among the selected predictors. Given the results of the PCA (Table S3), we decided to include sand content (as representative of soil capacity to retain and percolate water), soil bulk density and organic matter content as variables representative of the edaphic conditions in each stand. The topographic variables were calculated from a SRTMV1 digital elevation model with a $1-\mathrm{km}^{2}$ spatial resolution (Shuttle Radar Topographic Mission, http://www2.jpl. nasa.gov/srtm/) and included slope (degrees) and a topographic radiation index. This last variable was calculated from the slope and aspect (degrees) as cos(aspect)*slope/100, with a value of zero for a flat surface, negative for a southern exposure and positive for a northern exposure (Dietze \& Moorcroft, 2011).

The biotic variables considered were conspecific (Q. suber) and heterospecific (all other tree species) basal area in each stand $\left(\mathrm{m}^{2} \mathrm{ha}^{-1}\right)$. Correlation between all potential predictors was lower than 0.4. In an exploratory analysis, we found that the proportion of dead trees in the selected sites was similar across size classes, so we did not include size as a factor in the analysis. To improve model runs and to be able to make direct comparisons among parameter values, previous to the analysis, we standardized all the continuous explanatory variables by subtracting the mean and dividing by the standard deviation.

\section{Data analysis}

We tried several combinations of explanatory variables and of model structure (e.g. hierarchical estimation of the parameters, inclusion of spatial random effects). We first included climatic variables only, as temperature and precipitation are recognized as the main environmental variables associated with the decline processes (Carnicer et al., 2011), and then included additional explanatory variables (edaphic, topographic and biotic) and their interactions with climate. We describe our final models below, and these were the model structures and combination of explanatory variables that best fitted the data based on predicted loss (D, Gelfand \& Ghosh, 1998) which considers the goodness-of-fit of the model and a penalty term (the predictive variance). Models with the smallest $\mathrm{D}$ were a better fit to the data (for a list of other 
alternative models and combination of explanatory variables we tried see Tables S4 and S5).

\section{Analysis of tree survival}

To analyse tree survival as a function of several environmental and biotic variables, we used adult census data for the two times, $\mathrm{N}_{1}$ and $\mathrm{N}_{2}$ in a binomial likelihood where trees survived between censuses with probability $\theta$. We related $\theta$ to the explanatory variables using a logit link function (see Appendix S1 for further explanation).

\section{Analysis of regeneration patterns}

For the analysis of recruitment data (SFNI3), we split the data into two groups: seedlings less than $1.30 \mathrm{~m}$ height (seedling group hereafter; we considered together the two-first categories in SFNI3, see Table S6) and saplings, individuals higher than 1.30 and dbh smaller than $7.5 \mathrm{~cm}$ (sapling group hereafter, considering together categories three and four in SFNI3, see Table S6). We separated between seedlings and saplings, as plants within these two life stages can respond differently to environmental factors (Plieninger et al., 2010). For the analysis of both seedling and sapling abundance, we considered that analysing the number of individuals at one time (i.e. SFNI3) for the two life stages was appropriate to get accurate insights on the success or failure of recruitment at these stages. This approach may have some limitations relating to saplings, whose differences between inventories could have been more precise to evaluate their performance. Nevertheless, due the nature of the data, we could not have discerned the reason of the differences in rates (i.e. sapling mortality rate or sapling recruitment rate, Vayreda et al., 2013), and thus, a survival analysis between the two censuses and the abundance analysis for just one would be equivalent. As counts were recorded in ordinal categories, we used the average count for each of them: zero for plots without recruits, 2 for low (1-4), 10 for medium (5-15) and 20 for high $(>15)$, and the exact number of saplings in category 4 of the SIFN3. Models were fitted to each group separately. For the analysis of the sapling group, we considered as an additional explanatory variable the seedlings and saplings in category 1 in the first census (SFNI2, see Table S6). This is because it can influence sapling abundance by acting as a 'recruit bank' (Plieninger et al., 2010).

In the analysis of the seedling group, we defined the likelihood using a zero-inflated Poisson (Zuur et al., 2009) distribution with mean parameter $\mu$. For the final model, the probability of a zero count was given by $\omega$. We then related the parameter $\mu$ from the Poisson distribution to the explanatory variables using a log link function (see Appendix S2 for more detail).

For the analysis of the sapling group, we evaluated the abundance of saplings in those stands where they were present (71 stands in total). We used a Poisson likelihood (with parameter $\mu$ ) to model the abundance of saplings recorded in the second census (SFNI3). We related the parameter $\mu$ from the Poisson distribution to the explanatory variables using a log link function (see Appendix S3 for more detail).

We followed a Bayesian approach to estimate the parameters of the adult tree survival and recruitment models (see Appendix S4). Bayesian modelling allowed us to track the different sources of uncertainty inherent in the analysis, that is, the data, the process and the parameters (Clark, 2005). Parameters were estimated from non-informative prior distributions (see Appendix S4). Posterior densities of the parameters were obtained by Gibbs sampling (Geman \& Geman, 1984) using OpenBUGS 3.1.2. (Thomas et al., 2006). Models were run until convergence of the parameters was reached (c. 150,000 iterations), and parameters and their confidence intervals were estimated after discarding pre-converge 'burn-in' iterations (c. 10,000). Plots of predicted vs. observed values were also used to evaluate the fit of the model (unbiased model having a slope of unity). $R^{2}$ of observed vs. predicted values was used as a measure of goodness-of-fit. Fixed effects coefficients whose 95\% credible intervals did not include zero were considered statistically significant.

\section{Prediction of climate change effects}

We also sought to forecast the most likely trends on the dynamics of this species under future conditions, in particular how the interaction between climate and other factors might affect cork oak dynamics. We used parameter values (mean, variances and covariances) from the model runs to predict changes in tree survival and recruitment under different climatic scenarios. To do this, we used a space-for-time substitution approach where variations in $Q$. suber demography along spatial climatic gradients reflected in our data were used to infer potential species responses to future changes in climate. Hence, to examine the potential effects of forecasted temperature increases (IPCC, 2007; Planton et al., 2012), we used a mean predicted increase in $3{ }^{\circ} \mathrm{C}$ within each stand (mean of $\mathrm{A} 2$ and $\mathrm{B} 2$ regional predictions for 2070-2100) to predict survival and regeneration and compared these predicted values with current conditions.

\section{RESULTS}

\section{Tree survival patterns}

The fit of the best model predicting the data had an $R^{2}=0.54$ and a slope $=1.00$ (Tables 1 and S4). The final model included the following: winter precipitation, spring temperature, slope, topographic radiation index, sand content, sand*winter precipitation and heterospecific basal area. In this model, temperature in spring and the interaction between winter precipitation and soil sand content were the most important variables affecting the survival of adult cork oak (Table 1, Fig. 1). In sandy soils, the effect of increased winter precipitation was positive, whereas in heavier soils, 
the effect was the opposite (i.e. tree survival decreased for higher precipitation, Fig. 2). In flat areas, there was a tendency for higher survival, whereas steeper soils translated into lower probability of survival (Fig. 1). Similarly, there was a tendency of lower probability of survival at northern exposure compared with southern exposure (negative value of the parameter, Fig. 1). We also found that the presence and abundance of other species were associated with a decrease in the probability of cork oak survival (Table 1, Figs 1 and 3).

\section{Regeneration patterns}

In the analysis of the seedling group, the best model's $R^{2}$ between observed and predicted values was 0.18 and slope 0.92 (Tables 2 and S5). The final model included the following: winter precipitation, winter temperature, their interaction, slope and heterospecific basal area (Table 2).

Increasing winter temperatures had a positive effect on recruitment (Fig. 1), and there was a trend, although not significant, for higher precipitation favouring seedling

Table 1 Parameter estimates for the best model analysing mature tree survival. Values are posterior means \pm SD and $95 \%$ credible intervals. Bold values indicate coefficients that do not include zero in their credible intervals and denote a significant effect of the variable on survival. Letters indicate comparison: same letter indicates not differences between regions, and different letters indicate differences between regions

\begin{tabular}{|c|c|}
\hline Parameter & Values \\
\hline$\alpha 1$, wet region intercept & $\begin{array}{l}3.90 \pm 0.25 \mathrm{a} \\
3.42,4.42\end{array}$ \\
\hline$\alpha 2$, dry region intercept & $\begin{array}{l}3.65 \pm 0.37 \mathrm{a} \\
2.94,4.41\end{array}$ \\
\hline$\beta 1$, winter precipitation & $\begin{array}{l}-0.09 \pm 0.39 \\
-0.87,0.61\end{array}$ \\
\hline$\beta 2$, winter temperature & $\begin{array}{l}-0.89 \pm 0.30 \\
-1.48,-0.26\end{array}$ \\
\hline$\beta 3$, slope & $\begin{array}{l}-0.44 \pm 0.24 \\
-0.91,0.04\end{array}$ \\
\hline$\beta 4$, topographic radiation index & $\begin{array}{l}-0.42 \pm 0.18 \\
-0.79,-0.06\end{array}$ \\
\hline$\beta 5$, sand content & $\begin{aligned} 0.02 & \pm 0.24 \\
-0.44, & 0.49\end{aligned}$ \\
\hline$\beta 6$, sand content $*$ precipitation in winter & $\begin{array}{l}1.25 \pm 0.54 \\
0.19,2.30\end{array}$ \\
\hline$\beta 7$, heterospecific basal area & $\begin{array}{l}-0.71 \pm 0.24 \\
-1.16,-0.12\end{array}$ \\
\hline$\sigma^{2}$, wet region & $\begin{array}{l}2.56 \pm 0.39 \\
1.96,3.57\end{array}$ \\
\hline$\sigma^{2}$, dry region & $\begin{array}{l}2.08 \pm 0.57 \\
1.38,3.85\end{array}$ \\
\hline$\rho$, wet region & $\begin{array}{l}0.99 \pm 0.91 \\
0.02,3.51\end{array}$ \\
\hline$\rho$, dry region & $\begin{array}{l}0.99 \pm 1.01 \\
0.03,2.86\end{array}$ \\
\hline
\end{tabular}

recruitment. However, the winter temperature $\times$ precipitation interaction term was negative, meaning that recruitment would be favoured under warmer temperatures and drier conditions, diminishing the positive effect of warmer temperatures under wetter conditions (Figs 1 and 4). Given the parameter values and the credible intervals, the effect of the slope, although not statistically significant, was of biological relevance, showing less recruitment in steeper areas (Fig. 1). The presence of heterospecific trees had negative effect on this stage of recruitment (Fig. 3). Actual parameter values, standard deviation and 95\% confidence interval are reported in Table 2.

From the analysis of the sapling group for which we had 74 plots, the value of predicted loss for all of the models did not improve the fit of the model when compared with the climate only model (see Table S7). However, the variables included in this model (mean annual temperature and spring precipitation) were not significant (i.e. the 95\% confidence interval included zero, Table 2). Despite the findings on seedling patterns affected by different environmental factors, the scarcity of individuals found at the sapling stage could have hampered the detection of any effects at this stage.

\section{Prediction of climate change effect}

Based on the response of the studied variables along spatial environmental gradients, we predicted that under an intermediate scenario of $3{ }^{\circ} \mathrm{C}$ temperature increase, the probability of tree survival decreased compared with current conditions (Fig. 2), whereas recruitment abundance increased, especially noticeable under drier conditions (Fig. 4). Changes in precipitation would affect adult tree survival differently depending on the texture of soil, increasing in sandy soils and decreasing in heavier soils. Increase in precipitation would favour recruitment abundance, but this benefit would be less clear under higher temperatures.

\section{DISCUSSION}

There is the potential that future climatic trends will differently affect the life stages of organisms. It will be then the net effect along the life span of individuals that will determine the overall population response to future conditions. In this study, we investigated how climatic conditions influence Q. suber adult survival and seedling recruitment. Interestingly, our analysis showed contrasting responses of the two life stages studied (adult vs. seedling regeneration) to an increase in temperature, being detrimental for adult trees but beneficial for seedling recruitment. Furthermore, we found that soil conditions seem to modulate the effect of climate on adult tree survival by regulating the availability of water during the dry season. These results emphasize the need for simultaneously evaluating different life stages when studying plant population dynamics in response to varying environmental factors and highlight the importance of considering climate together with other interacting variables, in our case 
Figure 1 Posterior mean parameter values for each of the variables included in the adult tree survival (black dots) and seedling recruitment (white diamonds) analyses. Symbols for each variable are shown only when the variable was included in the final model. Bars indicate the $95 \%$ credible interval. Coefficients that do not include zero in their credible intervals are considered statistically significant.

Figure 2 Predicted mean effect of precipitation on the probability of adult survival for soils with different sand content in the wet region (a) and the dry region (b). Effect under the mean temperature (black colour) and the effect of $3{ }^{\circ} \mathrm{C}$ temperature increase (grey colour) are shown. The solid line is the mean of the posterior predictions, and the broken lines represent the $95 \%$ predicted interval, for the two regions. Winter precipitation is limited to the range found for this variable in each region.
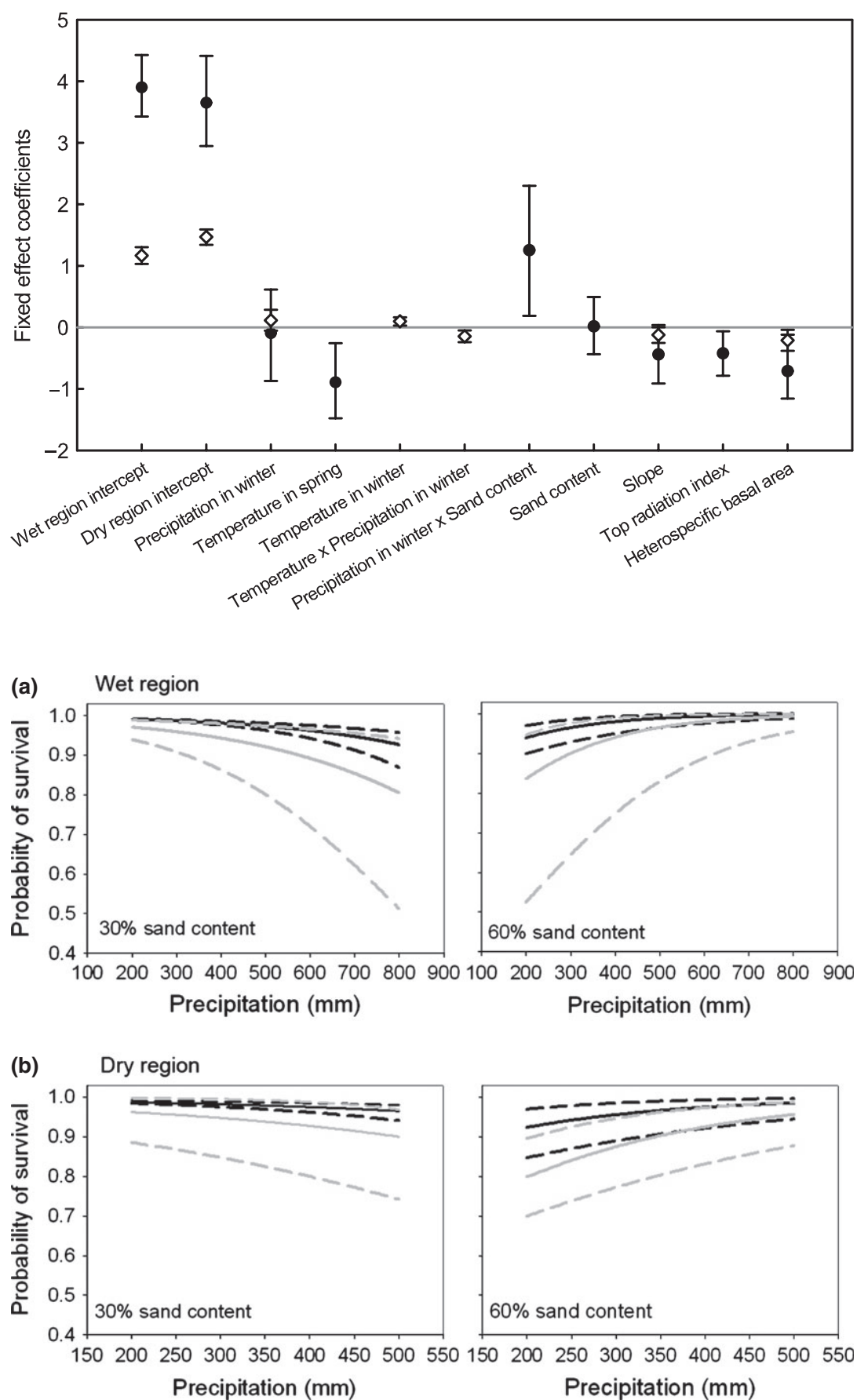

soil properties, when studying forest responses to future climates.

\section{Tree survival patterns}

Our results illustrate how adult tree survival was not only influenced by climate, in this case temperature in the spring having a negative effect, but also by the interaction between winter precipitation and soil texture. Spring is the season when mediterranean plants reach their maximum photosynthetic rates (Ogaya \& Peñuelas, 2003); thus, plants in this region are especially sensitive to environmental conditions during this season (Peñuelas et al., 2002; Gordo \& Sanz, 2010). Increased spring temperature may accelerate depletion of starch pools leading to carbon starvation and subsequent mortality during a drought year, according to the C-starvation hypothesis (McDowell \& Sevanto, 2010).

One of the main results derived from our study is the important role played by soil texture as a modulator of winter precipitation effects on adult survival. Soil texture determines soil hydrological properties (water infiltration, retention and runoff) and, ultimately, soil water availability (Weltzin et al., 2003). As expected, our results showed higher tree survival with higher winter precipitation, but 

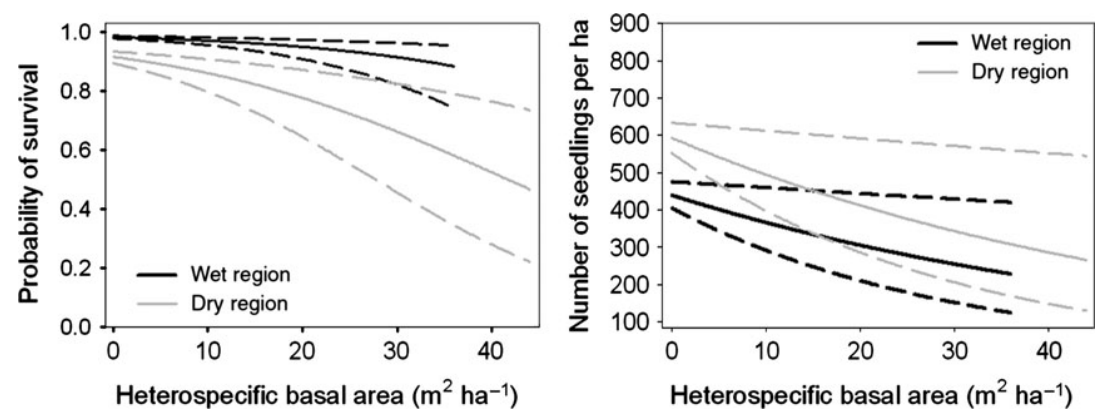

Figure 3 Mean effect of heterospecific abundance (basal area) on mature tree cork oak survival, left panel, and seedling recruitment, right panel, in the wet (black line) and dry (grey line) regions. The solid line is the mean of the posterior predictions, and the broken lines represent the $95 \%$ predicted interval. Heterospecific basal area is limited to the range found for this variable in each region.

Table 2 Parameter estimates for the best model analysing seedling and sapling abundance. Values are posterior means \pm SD and 95\% credible intervals. Bold values indicate coefficients that do not include zero in their credible intervals and denote a significant effect of the variable on abundance. Letters indicate comparison: same letter indicates not differences between regions, and different letter indicates differences between regions

\begin{tabular}{|c|c|}
\hline Parameter & Values \\
\hline \multicolumn{2}{|l|}{ Seedling group } \\
\hline$\gamma_{1}$, wet region intercept & $\begin{array}{l}1.17 \pm 0.07 \mathrm{a} \\
1.031,1.303\end{array}$ \\
\hline$\gamma_{2}$, dry region intercept & $\begin{array}{l}1.47 \pm 0.06 \mathrm{~b} \\
1.341,1.591\end{array}$ \\
\hline$\phi_{1}$, winter precipitation & $\begin{array}{l}0.11 \pm 0.09 \\
-0.05,0.29\end{array}$ \\
\hline$\phi_{2}$, winter temperature & $\begin{array}{l}0.10 \pm 0.03 \\
0.03,0.16\end{array}$ \\
\hline$\phi_{3}$, winter temperature $*$ winter precipitation & $\begin{array}{l}-0.14 \pm 0.05 \\
-0.24,-0.05\end{array}$ \\
\hline$\phi_{4}$, slope & $\begin{array}{l}-0.12 \pm 0.06 \\
-0.25,0.00\end{array}$ \\
\hline$\phi_{5}$, heterospecific basal area & $\begin{array}{l}-0.21 \pm 0.09 \\
-0.38,-0.04\end{array}$ \\
\hline$\sigma^{2}$, wet region & $\begin{array}{l}0.05 \pm 0.01 \\
0.03,0.08\end{array}$ \\
\hline$\sigma^{2}$, dry region & $\begin{array}{l}0.06 \pm 0.02 \\
0.02,0.13\end{array}$ \\
\hline$\rho$, wet region & $\begin{array}{l}1.025 \pm 0.99 \\
0.02,3.51\end{array}$ \\
\hline$\rho$, dry region & $\begin{array}{l}0.93 \pm 0.92 \\
0.02,3.31\end{array}$ \\
\hline \multicolumn{2}{|l|}{ Sapling group } \\
\hline$\gamma_{1}$, wet region intercept & $\begin{array}{l}1.44 \pm 0.18 \mathrm{a} \\
1.09,1.80\end{array}$ \\
\hline$\gamma_{2}$, dry region intercept & $\begin{array}{l}1.50 \pm 0.19 a \\
1.12,1.87\end{array}$ \\
\hline$\phi_{1}$, annual temperature & $\begin{aligned} 0.10 & \pm 0.24 \\
-0.37, & 0.56\end{aligned}$ \\
\hline$\phi_{2}$, precipitation in spring & $\begin{array}{l}-0.20 \pm 0.30 \\
-0.79,0.41\end{array}$ \\
\hline
\end{tabular}

surprisingly only in sandier soils. The positive effect of increase precipitation on sandy soils is probably due to the fact that rainfall percolates to deeper soil layers, ensuring the availability of water in the dry season (Brady \& Weil, 1996). On the contrary, on clayish soils, characterized by poor drainage capacity, water tends to accumulate and produce temporal waterlogging conditions. Waterlogging negatively affects cork oak survival both directly due to lack of aeration (Gaertig et al., 2002) and indirectly by favouring the accumulation of aggressive soil-borne pathogens (Gómez-Aparicio et al., 2012), such as Pythopthora cinnamomi, the main soil-borne pathogen related to the decline of cork oak in the area (Tuset \& Sánchez, 2004). Altogether, our results corroborate that soil texture is a key variable regulating the effects of varying climatic conditions on this species (FernandezIllescas et al., 2001; Piedallu et al., 2012). Consequently, although precipitation may be a good proxy for soil water availability to plants at very large scales, that is, regionally, soil hydrological properties have to be taken into account at smaller scales to fully describe the effects of changes on precipitation regime on plants.

In our analyses, we also found that biotic factors, in this case density of heterospecific species, had an effect on cork oak's adult survival. Unlike cool temperate forest systems where light is recognized as the major limiting factor for growth (e.g. Canham, 1988), in mediterranean climates, water availability is generally the most limiting resource (Carnicer et al., 2011). The negative relationship between the abundance of heterospecifics and cork oak survival could then be related to competition for water resources. This result agrees with previous studies that have found an increase in the sensitivity of evergreen oaks to competition with decreasing precipitation (Gómez-Aparicio et al., 2011). Nevertheless, we did not find any effect of conspecific trees on cork oak survival suggesting that interspecific competition for cork oak may be greater than intraspecific competition (Gómez-Aparicio et al., 2011).

\section{Recruitment patterns}

Similar to what we found for adult survival, climatic variables had the most influence determining Q. suber 

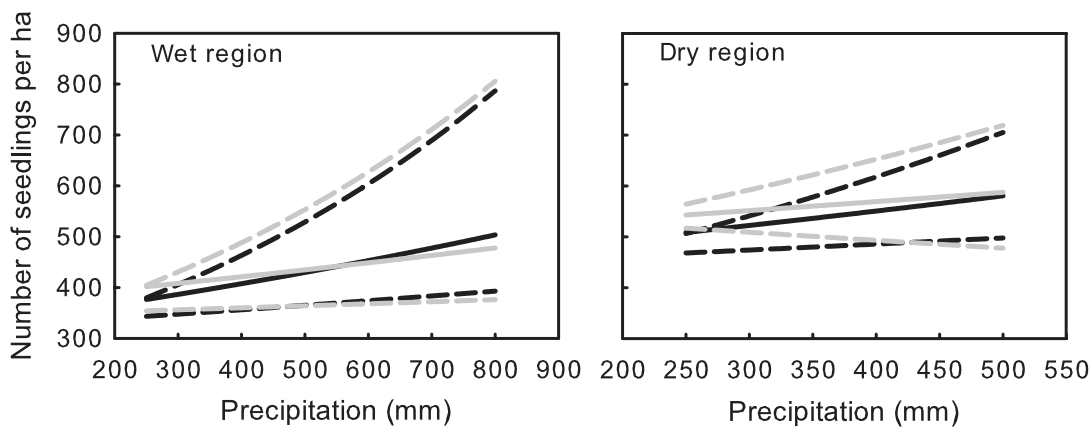

Figure 4 Predicted mean effect of precipitation on seedlings abundance (number of seedlings per hectare). Effects under the mean temperature (black colour) and under a $3{ }^{\circ} \mathrm{C}$ temperature increase (grey colour) are shown. The solid line is the mean of the posterior predictions, and the broken lines represent the $95 \%$ predicted interval, for the two regions. Winter precipitation is limited to the range found for each variable in each region.

regeneration dynamics. Nevertheless, the effects of climatic factors on recruitment of new individuals did not completely match with those from the adult trees analysis: seedling abundance was mainly affected by temperature in winter, with a positive response to warmer conditions, while adult tree survival responded negatively to spring temperatures. In addition, while our model provides very useful information for assessing recruitment, the $R^{2}$ obtained suggests that other factors are likely affecting the observed recruitment patterns.

The different response to seasonal temperatures between seedlings and adult trees may be due to the high sensitivity of cork oak seedlings to low winter temperatures (Aranda et al., 2005). In fact, low temperatures have a more negative impact on the photochemistry of cork oak leaves than do low water availability and high temperatures in summer (Aranda et al., 2005). Contrary to what we expected, the interaction between temperature and precipitation showed in our models could indicate that the positive effect of precipitation on the abundance of seedlings may be weaker under warmer temperatures. This surprising result seems to indicate that the effect of climate on cork oak recruitment could be largely mediated by indirect mechanisms related to the presence of soil-borne pathogens, whose abundance is favoured by soil moisture and warmer temperatures (Hendrix \& Campbell, 1973; Sánchez et al., 2002).

Here, again our models showed a negative effect of heterospecific trees on seedling recruitment. In the case of seedling recruitment, the negative effect that heterospecific trees seemed to have on recruitment may be due to competition for light. Some of the most common heterospecific species in our study sites (e.g. Quercus canariensis) create deep shade microsites under their canopy. Cork oak is a species of intermediate shade tolerance, and at low light levels, seedlings tend to allocate resources to leaves at the expense of the root system, preventing roots from reaching deeper water sources (e.g. Lloret et al., 1999; Cardillo \& Bernal, 2006). Still, the apparently lack of effect from conspecific adults on seedling abundance could be the result of several factors acting simultaneously with an overall neutral effect, a positive effect as seed producers but a negative effect due to the accumulation of host-specific enemies like soil pathogens or herbivores according to the Janzen-Connell hypothesis (e.g. Clark \& Clark, 1984).

\section{Predictions under forecasted climate change scenarios}

According to our model results, adult trees would respond negatively to warmer springs, and therefore, the predicted changes in climatic conditions could threaten the persistence of this species and the ecosystems it supports (see examples of other forest systems around the world in van Mantgem et al., 2009; Allen et al., 2010; Vilà-Cabrera et al., 2012). Thus, our simulation forecasts illustrate how cork oak, a key species in the Mediterranean, would be affected by the predicted rise in temperature during the year (Brunet et al., 2007). Global warming would affect both adult tree survival (influenced negatively by higher temperature in spring) and potentially recruitment patterns (influenced positively by higher temperature in winter), and it will be the net effect that will determine future dynamics. What is more, in these mediterranean forests, the inherent low abundance of seedlings and saplings resulting from their limiting climatic (e.g. high seedling mortality during summer) and management (e.g. overgrazing) characteristics makes the process of transition exceedingly slow, which highlights the important consequences that the increase in tree mortality and lack of recruitment may have on the continuity of these forests.

While there is a clear trend of increasing seasonal average temperature, the predicted seasonal changes in precipitation are more variable for the Mediterranean region. Although decreases are expected in the annual average and in average precipitation for most months, winter precipitation, our key variable, is expected to increase up to $30-40 \%$, particularly in December and January (Brunet et al., 2007; Planton et al., 2012). Our results suggest that the predicted changes in precipitation could have very different effects on tree survival patterns depending on the characteristics of the soils, which 
modulate the influence of climate. Therefore, under the predicted future climate scenarios, cork oak persistence is more likely to occur in sandy soils compared with clayey soils.

Most studies forecasting future plant distributions are based only on climate, neglecting the role of soils explaining distribution patterns. In our study, we have shown how soil characteristics are of crucial importance when determining the influence of climate on tree dynamics. Furthermore, for a more accurate assessment on plant dynamics, different life stages should be studied simultaneously as their different responses to environmental factors could determine the sign of the overall effect with great implications on the community.

Our models provided us with important information about underlying drivers of regeneration and mortality processes along large-scale climatic gradients, which shows contrasting trends at different life stages. However, other underlying drivers of these processes, such as herbivory in regeneration patterns (e.g. Pulido et al., 2013) or biotic agents in mortality processes (e.g. Brasier et al., 1993), could alter the observed trends. In addition, our approach, a spacefor-time substitution, has several relevant limitations. Specifically, local adaptation of tree species and the interaction of climate with biotic factors might lead to departures from the forecasted results. Still, this approach is valuable and informative, as it provides us with realistic insights of the potential consequences of climate change on plant populations (e.g. Pearson \& Dawson, 2003; Thomas et al., 2004; Bradley et al., 2009; Gómez-Aparicio et al., 2011).

\section{ACKNOWLEDGEMENTS}

We thank María Anaya for preparing the soil database. We thank the MAGRAMA for granting access to the Spanish Forest Inventory data. This research was supported by the Ministerio de Ciencia e Innovación (MICIIN) projects INTERBOS-CGL2008-04503-C03-03 (MCI) and DIVERBOSCGL2011-30285-C02-01 (MCI) and the Junta de Andalucía project ANASINQUE-PGC2010-RNM-5782. BI was supported by a Formación de Personal Investigador (FPI)-MICINN grant and P.R.B. by a Formación de Personal Universitario (FPU)-MEC grant.

\section{REFERENCES}

Allen, C.D., Macalady, A.K., Chenchouni, H., Bachelet, D., McDowell, N., Vennetier, M., Kitzberger, T., Rigling, A., Breshears, D.D., Hogg, E.H., Gonzalez, P., Fensham, R., Zhang, Z., Castro, J., Demidova, N., Lim, J.H., Allard, G., Running, S.W., Semerci, A. \& Cobb, N. (2010) A global overview of drought and heat-induced tree mortality reveals emerging climate change risks for forests. Forest Ecology and Management, 259, 660-684.

Aranda, I., Castro, L., Alia, R., Pardos, J.A. \& Gil, L. (2005)

Low temperature during winter elicits differential responses among populations of the Mediterranean evergreen cork oak (Quercus suber). Tree Physiology, 25, 1085-1090.

Aronson, J., Pereira, J.S. \& Pausas, J.G. (2009) Cork oak woodlands on the edge: ecology, adaptive management, and restoration. Island Press, Washington, DC, USA.

Axelsson, A.L. \& Ostlund, L. (2001) Retrospective gap analysis in a Swedish boreal forest landscape using historical data. Forest Ecology and Management, 147, 109-122.

Bengtsson, J., Nilsson, S.G., Franc, A. \& Menozzi, P. (2000) Biodiversity, disturbances, ecosystem function and management of European forests. Forest Ecology and Management, 132, 39-50.

Bradley, B.A., Oppenheimer, M. \& Wilcove, D.S. (2009) Climate change and plant invasions: restoration opportunities ahead? Global Change Biology, 15, 1511-1521.

Brady, N.C. \& Weil, R.R. (1996) The nature and properties of soils, 14th edn. Prentice-Hall Inc., Upper Saddle River, NJ, USA.

Brasier, C.M. (1995) Phytophthora cinnamomi and oak decline in southern Europe. Environmental constraints including climate change. Annals des Sciences Forestières, 53, 347-358.

Brasier, C.M., Robredo, F. \& Ferraz, J.F.P. (1993) Evidence for Phytophthora cinnamomi involvement in Iberian oak decline. Plant Pathology, 42, 140-145.

Brudvig, L.A. \& Damschen, E.I. (2011) Land-use history, historical connectivity, and land management interact to determine longleaf pine woodland understory richness and composition. Ecography, 34, 257-266.

Brunet, M., Jones, P.D., Sigro, J., Saladie, O., Aguilar, E., Moberg, A., Della-Marta, P.M., Lister, D., Walther, A. \& Lopez, D. (2007) Temporal and spatial temperature variability and change over Spain during 1850-2005. Journal of Geophysical Research-Atmospheres, 112, D12117, doi: 10. 1029/2006JD008249

Bugalho, M.N., Caldeira, M.C., Pereira, J.S., Aronson, J. \& Pausas, J.G. (2011) Mediterranean cork oak savannas require human use to sustain biodiversity and ecosystem services. Frontiers in Ecology and the Environment, 9, 278286.

Canham, C.D. (1988) Growth and canopy architecture of shade-tolerant trees: response to canopy gaps. Ecology, 69, 786-795.

Canham, C.D. \& Pacala, S.W. (1994) Linking tree population dynamics and forest ecosystem processes. Chapman and Hall, New York, NY, USA.

Cardillo, E. \& Bernal, C.J. (2006) Morphological response and growth of cork oak (Quercus suber L.) seedlings at different shade levels. Forest Ecology and Management, 222, 296-301.

Carnicer, J., Coll, M., Ninyerola, M., Pons, X., Sanchez, G. \& Penuelas, J. (2011) Widespread crown condition decline, food web disruption, and amplified tree mortality with increased climate change-type drought. Proceedings of the National Academy of Sciences USA, 108, 1474-1478. 
Cavender-Bares, J. \& Bazzaz, F.A. (2000) Changes in drought response strategies with ontogeny in Quercus rubra: implications for scaling from seedlings to mature trees. Oecologia, 124, 8-18.

Clark, J.S. (2005) Why environmental scientists are becoming Bayesians. Ecology Letters, 8, 2-14.

Clark, D.A. \& Clark, D.B. (1984) Spacing dynamics of a tropical rain forest tree: evaluation of the Janzen-Connell model. The American Naturalist, 124, 769-788.

David, T.S., Ferreira, M.I., Cohen, S., Pereira, J.S. \& David, J.S. (2004) Constraints on transpiration from an evergreen oak tree in southern Portugal. Agricultural and Forest Meteorology, 122, 193-205.

De la Rosa, D. \& Monge, G. (2006) Incorporación de Nuevos Datos de Suelos e Integración de Modelos de Erosión (MicroLEIS) al Sistema Multiple de Análisis de los Cultivos por Teledetección (SIMANCTEL). Junta de Andalucía, Consejería de Agricultura, DAP, Sevilla.

De la Rosa, D., Mayol, F., Moreno, F., Cabrera, F., DiazPereira, E. \& Antoine, J. (2002) A multilingual soil profile database (SDBm Plus) as an essential part of land resources information systems. Environmental Modelling \& Software, 17, 721-730.

Dietze, M.C. \& Moorcroft, P.R. (2011) Tree mortality in the eastern and central United States: patterns and drivers. Global Change Biology, 17, 3312-3326.

Fernandez-Illescas, C.P., Porporato, A., Laio, F. \& RodriguezIturbe, I. (2001) The ecohydrological role of soil texture in a water-limited ecosystem. Water Resources Research, 37, 2863-2872.

Franklin, J.F., Shugart, H.H. \& Harmon, M.E. (1987) Tree death as an ecological process. BioScience, 37, 550-556.

Gaertig, T., Schack-Kirchner, H., Hildebrand, E.E. \& von Wilpert, K. (2002) The impact of soil aeration on oak decline in southwestern Germany. Forest Ecology and Management, 159, 15-25.

García, L.V., Ramo, C., Aponte, C., Moreno, A., Domínguez, M.T., Gomez-Aparicio, L., Redondo, R. \& Marañón, T. (2011) Protected wading bird species threaten relict centenarian cork oaks in a Mediterranean Biosphere Reserve: a conservation management conflict. Biological Conservation, 144, 764-771.

Gelfand, A.E. \& Ghosh, S.K. (1998) Model choice: a minimum posterior predictive loss approach. Biometrika, 85, 1-11.

Geman, S. \& Geman, D. (1984) Stochastic relaxation, Gibbs distributions, and the Bayesian restoration of images. Ieee Transactions on Pattern Analysis and Machine Intelligence, 6, 721-741.

Giorgi, F. \& Lionello, P. (2008) Climate change projections for the Mediterranean region. Global and Planetary Change, 63, 90-104.

Gómez-Aparicio, L., Garcia-Valdes, R., Ruiz-Benito, P. \& Zavala, M.A. (2011) Disentangling the relative importance of climate, size and competition on tree growth in Iberian forests: implications for forest management under global change. Global Change Biology, 17, 2400-2414.
Gómez-Aparicio, L., Pérez-Ramos, I.M., Mendoza, I., Matías, L., Quero, J.L., Castro, J., Zamora, R. \& Marañón, T. (2008) Oak seedling survival and growth along resource gradients in Mediterranean forests: implications for regeneration in current and future environmental scenarios. Oikos, 117, 1683-1699.

Gómez-Aparicio, L., Ibáñez, B., Serrano, M.S., De Vita, P., Ávila, J.M., Pérez-Ramos, I.M., García, L.V., Esperanza Sánchez, M. \& Marañón, T. (2012) Spatial patterns of soil pathogens in declining Mediterranean forests: implications for tree species regeneration. New Phytologist, 194, 10141024.

Gonzalo, J. (2008) Diagnosis fitoclimática de la España peninsular. Actualización y análisis geoestadístico aplicado. Universidad Politécnica de Madrid, Escuela Superior de Ingenieros de Montes, Madrid, Spain.

Gordo, O. \& Sanz, J.J. (2010) Impact of climate change on plant phenology in Mediterranean ecosystems. Global Change Biology, 16, 1082-1106.

He, J.-S., Zhang, Q.-B. \& Bazzaz, F.A. (2005) Differential drought responses between saplings and adult trees in four co-occurring species of New England. Trees - Structure and Function, 19, 442-450.

Hendrix, F.F. \& Campbell, W.A. (1973) Pythiums as plant pathogens. Annual Review of Phytopathology, 11, 77-98.

Ibáñez, I., Clark, J.S., LaDeau, S. \& HilleRisLambers, J. (2007) Exploiting temporal variability to understand tree recruitment response to climate change. Ecological Monographs, 77, 163-177.

IPCC (2007) Climate change 2007: the physical science basis. contribution of working group I to the fourth assessment report of the intergovernmental panel on climate change. Cambridge University Press, Cambridge, UK and NY.

Kobe, R.K. (1996) Intraspecific variation in sapling mortality and growth predicts geographic variation in forest composition. Ecological Monographs, 66, 181-201.

Lewis, S.L., Phillips, O.L., Sheil, D., Vinceti, B., Baker, T.R., Brown, S., Graham, A.W., Higuchi, N., Hilbert, D.W., Laurance, W.F., Lejoly, J., Malhi, Y., Monteagudo, A., Vargas, P.N., Sonke, B., Supardi, N., Terborgh, J.W. \& Martinez, R.V. (2004) Tropical forest tree mortality, recruitment and turnover rates: calculation, interpretation and comparison when census intervals vary. Journal of Ecology, 92, 929-944.

Lloret, F., Casanovas, C. \& Peñuelas, J. (1999) Seedling survival of Mediterranean shrubland species in relation to root:shoot ratio, seed size and water and nitrogen use. Functional Ecology, 13, 210-216.

Lloret, F., Peñuelas, J. \& Estiarte, M. (2004) Experimental evidence of reduced diversity of seedlings due to climate modification in a Mediterranean-type community. Global Change Biology, 10, 248-258.

Lloret, F., Peñuelas, J., Prieto, P., Llorens, L. \& Estiarte, M. (2009) Plant community changes induced by experimental climate change: Seedling and adult species composition. Perspectives in Plant Ecology, Evolution and Systematics, 11, 53-63. 
van Mantgem, P.J., Stephenson, N.L., Byrne, J.C., Daniels, L.D., Franklin, J.F., Fulé, P.Z., Harmon, M.E., Larson, A.J., Smith, J.M., Taylor, A.H. \& Veblen, T.T. (2009) Widespread increase of tree mortality rates in the western United States. Science, 323, 521-524.

Marañón, T., Ajbilou, R., Ojeda, F. \& Arroyo, J. (1999) Biodiversity of woody species in oak woodlands of southern Spain and northern Morocco. Forest Ecology and Management, 115, 147-156.

Marañón, T., Ibáñez, B., Anaya-Romero, M., Muñoz-Rojas, M. \& Pérez-Ramos, I.M. (2012) Oak trees and woodlands providing ecosystem services in Southern Spain. Trees beyond the Wood. An exploration of concepts of woods, forests and trees (ed. by I.D. Rotherham, C. Handley, M. Agnoletti and T. Samojlik), pp. 369-378, Wildtrack Publishing, Sheffield, UK.

McDowell, N.G. \& Sevanto, S. (2010) The mechanisms of carbon starvation: how, when, or does it even occur at all? New Phytologist, 186, 264-266.

Monge, G., Rodríguez, J.A., Anaya-Romero, M. \& de la Rosa, D. (2008) Generación de Mapas Lito-Edafológicos de Andalucía. Mapping Interactivo. International Journal of Geomatics and Earth Sciences, 124, 38-45.

Niinemets, Ü. (2010) Responses of forest trees to single and multiple environmental stresses from seedlings to mature plants: past stress history, stress interactions, tolerance and acclimation. Forest Ecology and Management, 260, 16231639.

Noble, I.R. \& Dirzo, R. (1997) Forests as human-dominated ecosystems. Science, 277, 522-525.

Ogaya, R. \& Peñuelas, J. (2003) Comparative seasonal gas exchange and chlorophyll fluorescence of two dominant woody species in a Holm Oak Forest. Flora-Morphology, Distribution, Functional Ecology of Plants, 198, 132-141.

Olea, L. \& San Miguel-Ayanz, A. (2006) The Spanish dehesa. A traditional Mediterranean silvopastoral system linking production and nature conservation. Grassland Science in Europe, 11, 3-13.

Pacala, S.W., Canham, C.D., Saponara, J. Jr, Silander, J.A. Jr, Kobe, R.K. \& Ribbens, E. (1996) Forest models defined by field measurements: estimation, error analysis and dynamics. Ecological Monographs, 66, 1-43.

Pausas, J., Marañón, T., Caldeira, M.C. \& Pons, J. (2009) Natural regeneration. Cork oak woodlands on the edge: ecology, adaptive management and restoration (ed. by J. Aronson, J.S. Pereira and J.G. Pausas), pp. 115-124. Island Press, Washington, DC, USA.

Pearson, R.G. \& Dawson, T.P. (2003) Predicting the impacts of climate change on the distribution of species: are bioclimate envelope models useful? Global Ecology and Biogeography, 12, 361-371.

Peñuelas, J., Filella, I. \& Comas, P. (2002) Changed plant and animal life cycles from 1952 to 2000 in the Mediterranean region. Global Change Biology, 8, 531-544.

Peñuelas, J., Ogaya, R., Boada, M. \& Jump, A.S. (2007) Migration, invasion and decline: changes in recruitment and forest structure in a warming-linked shift of European beech forest in Catalonia (NE Spain). Ecography, 30, 829-837.

Pérez-Ramos, I.M. \& Marañón, T. (2012) Community-level seedling dynamics in Mediterranean forests: uncoupling between the canopy and the seedling layers. Journal of Vegetation Science, 23, 526-540.

Phillips, O.L. \& Gentry, A.H. (1994) Increasing turnover through time in tropical forests. Science, 263, 954-958.

Piedallu, C., Gégout, J.-C., Perez, V., Lebourgeois, F. \& Field, R. (2012) Soil water balance performs better than climatic water variables in tree species distribution modelling. Global Ecology and Biogeography, 22, 470-482.

Planton, S., Lionello, P., Artale, V. et al. (2012) The climate of the Mediterranean region in future climate projections. The Climate of the Mediterranean Region (ed. by P. Lionello), pp. 449-502. Elsevier, Oxford.

Plieninger, T., Pulido, F.J. \& Konold, W. (2003) Effects of land-use history on size structure of holm oak stands in Spanish dehesas: implications for conservation and restoration. Environmental Conservation, 30, 61-70.

Plieninger, T., Rolo, V. \& Moreno, G. (2010) Large-scale patterns of Quercus ilex, Quercus suber, and Quercus pyrenaica regeneration in Central-Western Spain. Ecosystems, 13, 644-660.

Pulido, F.J. \& Díaz, M. (2005) Regeneration of a Mediterranean oak: a whole-cycle approach. Ecoscience, 12, 92-102.

Pulido, F., McCreary, D., Cañellas, I., McClaran, M. \& Plieninger, T. (2013) Oak regeneration: ecological dynamics and restoration techniques. Mediterranean oak woodland working landscapes. (ed. by P. Campos et al.), pp. 123-144. Springer, the Netherlands.

R Development Core Team (2009) R: a language and environment for statistical computing. $\mathrm{R}$ Foundation for Statistical Computing, Vienna, Austria.

Reyes-López, J., Ruiz, N. \& Fernández-Haeger, J. (2003) Community structure of ground-ants: the role of single trees in a Mediterranean pastureland. Acta Oecologica, 24, 195-202.

Sánchez, M.E., Caetano, P., Ferraz, J. \& Trapero, A. (2002) Phytophthora disease of Quercus ilex in south-western Spain. Forest Pathology, 32, 5-18.

Thomas, C.D., Cameron, A., Green, R.E., Bakkenes, M., Beaumont, L.J., Collingham, Y.C., Erasmus, B.F.N., de Siqueira, M.F., Grainger, A., Hannah, L., Hughes, L., Huntley, B., van Jaarsveld, A.S., Midgley, G.F., Miles, L., OrtegaHuerta, M.A., Peterson, A.T., Phillips, O.L. \& Williams, S.E. (2004) Extinction risk from climate change. Nature, 427, 145-148.

Thomas, A., O'Hara, R., Ligges, U. \& Sturts, S. (2006) Making BUGS open. $R$ news, 6, 12-17.

Tuset, J.J. \& Sánchez, G. (2004) La Seca: El decaimiento de encinas, alcornoques y otros Quercus en España. Ministerio de Medio Ambiente, Organismo Autónomo de Parques Nacionales, Madrid, Spain.

Urbieta, I.R., Zavala, M.A. \& Marañón, T. (2008) Human and non-human determinants of forest composition in 
southern Spain: evidence of shifts towards cork oak dominance as a result of management over the past century. Journal of Biogeography, 35, 1688-1700.

Urbieta, I.R., García, L.V., Zavala, M.A. \& Marañón, T. (2011) Mediterranean pine and oak distribution in southern Spain: is there a mismatch between regeneration and adult distribution? Journal of Vegetation Science, 22, 18-31.

Vayreda, J., Gracia, M., Martinez-Vilalta, J. \& Retana, J. (2013) Patterns and drivers of regeneration of tree species in forests of peninsular Spain. Journal of Biogeography, 40, $1252-1265$.

Vilà-Cabrera, A., Martínez-Vilalta, J., Galiano, L. \& Retana, J. (2012) Patterns of forest decline and regeneration across scots pine populations. Ecosystems, 16, 323-335.

Villaescusa, R. \& Díaz, R. (1998) Segundo inventario forestal nacional (1986-1996). Ministerio de Medio Ambiente, ICONA, Madrid, Spain.

Villanueva, J.A. (2004) Tercer inventario forestal nacional (1997-2007). Ministerio de Medio Ambiente, Madrid, Spain.

Weltzin, J.F., Loik, M.E., Schwinning, S., Williams, D.G., Fay, P.A., Haddad, B.M., Harte, J., Huxman, T.E., Knapp, A.K., Lin, G., Pockman, W.T., Shaw, M.R., Small, E.E., Smith, M.D., Smith, S.D., Tissue, D.T. \& Zak, J.C. (2003) Assessing the response of terrestrial ecosystems to potential changes in precipitation. BioScience, 53, 941-952.

Zuur, A.F., Ieno, E.N., Walker, N.J., Saveliev, A.A. \& Smith, G.M. (2009) Zero-truncated and zero-inflated models for count data. Mixed effects models and extensions in ecology with $R$ (ed. by A.F. Zuur, E.N. Ieno, N.J. Walker, A.A. Saveliev and G.M. Smith), pp. 261-293. Springer, New York, NY.

\section{SUPPORTING INFORMATION}

Additional Supporting Information may be found in the online version of this article:

Figure S1 Map showing the location of the area of study within Spain.

Appendix S1 Analytical methods: Analysis of tree survival.
Appendix S2 Analytical methods: Analysis of the seedling group.

Appendix S3 Analytical methods: Analysis of the sapling group.

Appendix S4 Analytical methods: Parameter estimation.

Table S1 Summary of the data on the selected sites.

Table S2 Mean ( \pm SD) and maximum and minimum values of the exploratory variables for each region.

Table S3 Factor loadings of varimax-rotated factors for the soil variables.

Table S4 Selected models used to evaluate the probability of mature tree survival.

Table S5 Selected models used to evaluate the number of seedlings less than $1.30 \mathrm{~m}$ high of cork oak.

Table S6 Classification of recruitment in the seedling and sapling groups.

Table S7 Predictive loss (D) for some of the models run in the analysis of saplings (> $1.30 \mathrm{~m}$ high).

\section{BIOSKETCH}

Beatriz Ibáñez is concluding her $\mathrm{PhD}$ under the supervision of T. Marañón, L. Gómez-Aparicio and L.V. García. She is studying the consequences of tree mortality and recruitment limitation in mediterranean forests affected by oak decline, aiming to gain knowledge on the functioning of these systems due to their ecological, economic and social importance.

Author contributions: B.I., T.M., L.G.A. and L.V.G. conceived this study; B.I. and I.I. analysed the data; P.R.B. adapted the database; all authors contributed to the writing of the manuscript.

Editor: Wilfried Thuiller 